\title{
Correction to: A Comprehensive Assessment of the Need and Availability of Smart Grid Technologies in an Electricity Distribution Grid Network
}

\author{
Sudhangshu Sarkar $^{1} \cdot$ Ushnik Chakrabarti $^{1} \cdot$ Suvamoy Bhattacharyya $^{1} \cdot$ \\ Amlan Chakrabarti ${ }^{1}$
}

Published online: 3 April 2021

(C) The Institution of Engineers (India) 2021

\section{Correction to: J. Inst. Eng. India Ser. B \\ (December 2020) 101(6):753-761 \\ https://doi.org/10.1007/s40031-020-00486-1}

The article A Comprehensive Assessment of the Need and Availability of Smart Grid Technologies in an Electricity Distribution Grid Network, written by Sudhangshu Sarkar, Ushnik Chakrabarti, Suvamoy Bhattacharyya, Amlan Chakrabarti was originally published online on 12 September 2020 with Open Access under a "Creative Commons Attribution 4.0 International License, which permits use, sharing, adaptation, distribution and reproduction in any medium or format, as long as you give appropriate credit to the original author(s) and the source, provide a link to the Creative Commons licence, and indicate if changes were made. The images or other third party material in this article are included in the article's Creative Commons licence, unless indicated otherwise in a credit line to the material. If material is not included in the article's Creative Commons licence and your intended use is not permitted by statutory regulation or exceeds the permitted use, you will need to obtain permission directly from the copyright holder. To view a copy of this licence, visit https://creativecommons.org/licenses/by/4.0/ iveco mmons.org/licen ses/by/4.0/"]. After publication in volume 101, issue 6, page 753-761 the author(s) decided to cancel the Open Access. Therefore, the copyright of the article has been changed on 30 March 2021 to (c) The Institution of Engineers (India) 2021 with all rights reserved.

The original article has been corrected.

Publisher's Note Springer Nature remains neutral with regard to jurisdictional claims in published maps and institutional affiliations.

The original article can be found online at https://doi.org/10.1007/s40031-020-00486-1.

Sudhangshu Sarkar

sarkar.sudhangshu@gmail.com

Ushnik Chakrabarti

ushnikchakrabarti@gmail.com

Suvamoy Bhattacharyya

suvamoy.bhattacharyya@gmail.com

Amlan Chakrabarti

amlanc@hotmail.com

1 Department of Electrical Engineering, Narula Institute of Technology, Kolkata, India 